\title{
Environmental Assessment of Different Cement Manufacturing Processes Based on Emergy and Ecological Footprint Analysis
}

Article in Journal of Cleaner Production · February 2016

Impact Factor: 3.84 · DOI: 10.1016/j.jclepro.2016.01.087

READS

42

4 authors, including:

Hrvoje Mikulcic

University of Zagreb

26 PUBLICATIONS 95 CITATIONS

SEE PROFILE
Neven Duic

University of Zagreb

406 PUBLICATIONS 1,569 CITATIONS

SEE PROFILE 
Please cite as: Mikulčić, H., et al., Environmental assessment of different cement manufacturing processes based on Emergy and Ecological Footprint analysis, Journal of Cleaner Production (2016), http://dx.doi.org/10.1016/j.jclepro.2016.01.087

\section{Environmental Assessment of Different Cement Manufacturing Processes}

\section{Abstract}

\section{Based on Emergy and Ecological Footprint Analysis}

\author{
${ }^{1, *} \underline{\text { Hrvoje Mikulčić}},{ }^{2}$ Heriberto Cabezas, ${ }^{1}$ Milan Vujanović, ${ }^{1}$ Neven Duić \\ ${ }^{1}$ Faculty of Mechanical Engineering and Naval Architecture, University of Zagreb, \\ Ivana Lučića 5, 10000 Zagreb, Croatia, \\ E-mails:hrvoje.mikulcic@fsb.hr,milan.vujanovic@fsb.hr,neven.duic@fsb.hr \\ ${ }^{2}$ U.S. Environmental Protection Agency \\ Office of Research and Development \\ National Risk Management Research Laboratory \\ Cincinnati, Ohio, U.S.A., \\ E-mail: Cabezas.Heriberto@epa.gov
}


Keywords: Sustainable cement production; Cement industry; Mitigation scenario,

2 Emergy; Ecological Footprint

\section{Introduction}

Climate change problems are addressed by two major international agreements: the 1992 United Nations Framework Convention on Climate Change (UNFCCC) and the 1997 Kyoto Protocol (IPCC, 2013). The ultimate objective of these agreements is to stabilise greenhouse gas - GHG concentrations in the atmosphere at a level that would prevent dangerous anthropogenic interference with the global climate system. The latest report from the scientific panel on anthropogenic global warming indicates that substantial and joint global action is required to reduce carbon dioxide $-\mathrm{CO}_{2}$ emissions. Meaning the longer we wait to address this issue, the more difficult, technologically challenging and expensive it becomes (IPCC, 2014).

It is well known that over $80 \%$ of global $\mathrm{CO}_{2}$ emissions are caused by transport activities and industry due to this reason, there is a need to decarbonize transport and industrial production (Klemeš et al., 2012). In 2008, the electricity and heat generation sector was responsible for $41 \%$, transport sector for $22 \%$, and industry for $20 \%$ of anthropogenic $\mathrm{CO}_{2}$ emissions (Benhelal et al., 2013). From these $20 \%$ of global $\mathrm{CO}_{2}$ emissions related to industry, the cement industry accounts for approximately a quarter of total $\mathrm{CO}_{2}$ emissions in industry (Marques and Neves-Silva, 2015). This means that cement industry as an energy intensive industrial sector, alone generates approximately $5 \%$ of anthropogenic $\mathrm{CO}_{2}$ in the world, and this figure is given in several studies (Mikulčić et al., 2013a; Usón et al., 2013). Due to its significant environmental impact, over the past decades several $\mathrm{CO}_{2}$ emissions mitigation measures have appeared. The main objective of these measures is environmental conservation in terms of reducing $\mathrm{CO}_{2}$ emissions.

In recent years, there have been numerous studies worldwide discussing energy conservation policies, estimating the $\mathrm{CO}_{2}$ mitigation potential, and considering technology evaluation for the cement industry. Some of these studies investigated the effect of mitigation measures at the global level, such as the study conducted by the International Energy Agency - IEA (IEA, 2009). However, the majority of these studies evaluated the environmental impact of cement production at national and regional levels. The effect of mitigation measures on the regional level, like those in the European Union - EU were analyzed in Pardo et al. (2011) and 33 Moya et al. (2011). The United States' cement industry was analysed in the study by Xu et al. 
1 (2013). However due to the rapid economic growth and vast urbanization, the majority of the

2 studies related to the cement industry are for the developing countries like China ( $\mathrm{Li}$ et al., 3 2014; Wang et al., 2014; Xu et al., 2014 ), South Africa (Swanepoel et al., 2014), Turkey 4 (Ekincioglu et al., 2013), Iran (Ostad-Ahmad-Ghorabi and Attari, 2013), India (Morrow et al., 2014), Thailand (Hasanbeigi et al., 2010), and Vietnam (Nguyen and Hens, 2013). The reason for these is most easily seen in Table 1 where the global cement production for 2012 is given. Table 1 shows that the vast majority of cement production is located in developing countries, especially in Asia. The importance of cement production in these developing economies can also be observed when comparing the annual $\mathrm{CO}_{2}$ emissions from cement production in industrialised countries and developing countries. In the EU, the cement industry contributes to about $4.1 \%$ of total $\mathrm{CO}_{2}$ emissions (Mikulčić et al., 2013b). This share varies from one EU country to another, in EU's most developed country Germany, this share is even lower, and the cement industry accounts for $2.9 \%$ of Germany's $\mathrm{CO}_{2}$ emissions (Brunke and Blesl, 2014). This is similar for the cement industry in United States, where cement production is responsible for about $2 \%$ of total $\mathrm{CO}_{2}$ emissions (Worrell and Galitsky, 2008). Whereas in China, the world's largest cement producing country and the world's largest emitter of GHG emissions, $15 \%$ of total $\mathrm{CO}_{2}$ emissions are related to cement production (Chen et al., 2014; Wang et al., 2013). All of these studies stated that there is a great challenge in attempting to approach sustainability in the cement industry. Due to this reason and the increased social awareness in fighting climate changes, eco-labelling of companies, products, lifestyle, services, etc., is becoming an element of decision making (Čuček et al., 2012a).

Over the years, Ecological Footprint has arisen as a simple, yet effective tool that can serve as an indicator of environmental impact, and eco-labelling (Cagiao et al., 2011; Čuček et al., 2012b). However, Huijbregts et al. (2008) in their study show that the usefulness of the Ecological Footprint as a stand-alone indicator for the environmental impact is limited. Based on their observations, they concluded that the Ecological Footprint should be used together with other indicators to estimate in detail the impact of human activities on the environment. This observation was even more highlighted recently by Rugani et al. (2013), where it was concluded that the use of the Carbon Footprint in combination with other single-issue indicators would be recommended to increase transparency and impacts coverage.

As cement manufacturing is an energy intensive process, Emergy was used as an indicator for sustainability in some studies. Pulselli et al. (2008) in their study through an 
1 et al. (2011) showed that Emergy analysis provides results that measure the resource input in the cement industry. These results can be further used for process performance analysis. Liu et al. (2014) used emergy analysis and evaluated the environmental effect of using sewage sludge as an alternative raw material or fuel in clinker production. The study showed that the use of emergy accounting may provide quantitative metrics of eco-industrial sustainability. In a recent study by Jamali-Zghal et al. (2013), Emergy and Carbon Footprint were used together to study to which extent, replacing fossil fuel with biomass for heating is an environmentally friendly solution. In relation to this study, Andrić et al. (2014) using the same approach for electricity production determined the maximum supply distance of biomass that allows the cofiring of coal and biomass to be more environmentally efficient than the pure coal combustion. The study showed that the Carbon Footprint and Emergy method are used together to cover all, or at least most, of the significant aspects of the electricity production process that may influence the environment.

To date, to the knowledge of the authors, there have been no studies that used the Emergy and Ecological Footprint together as environmental indicators, to investigate the sustainability of cement manufacturing processes. For that reason in this study, in order to help cement manufactures to operate in a more environmental friendly way, and to assess which manufacturing process is more sustainable, the environmental impact of four different cement manufacturing processes is estimated. Actual cement plant data is used in order to correctly study the impact of different processes. The results shown in this study highlight potential modifications and improvements in the manufacturing process, regarding its sustainability.

\section{Methodology}

Sustainability is essentially about finding ways to meet the material and energy needs of human society within the limits of planet Earth over the long term (WCED, 1987). In the case of manufacturing activities, sustainability goes beyond pollution prevention by extending the time frame and the functional scope of the analysis. Extending the time frame implies that processes must be capable of functioning in an environmentally acceptable manner for a very long time. Extending the functional scope of the analysis means that the manufacturing activity must be able to function without seriously impairing the natural processes of the environment in which it is imbedded. These natural processes include things such as waste dissipation, nutrient cycling, oxygen production, and many others. For these processes to function there are some conditions that must be maintained such as having: (1) as small of a 
1 footprint on the environment as possible and (2) as small of an appropriation of the energy

2 resources of the environment as possible. These two are not necessarily the only two issues of concern. But they are important for technological processes, and they can be expressed quite generally as will be shown shortly. They also can inherently incorporate many specific sustainability issues such greenhouse gas emissions, land use, and water depletion.

It is very important, however, that environmental issues not be ported from one media or area to another. For example, reducing energy consumption at the cost of increased water usage, thus reducing one kind of environmental impact only to increase another. To mitigate this problem, we use integrated sustainability metrics where many effects across the life-cycle are incorporated into common measures. Hence, we account for the use of land with the Ecological Footprint - EF (Wackernagel and Rees, 1996) and for energy resources using Emergy Analysis - Em (Odum and Nilsson, 1996) as will be discussed further in the following sections. The application of Ecological Footprint (Vance et al., 2013) and Ecological Footprint and Emergy Analysis (Vance et al., 2015) to the design of energy supply chains can be found in the literature.

Ecological Footprint and Emergy Analysis speak to sustainability because, when comparing two options, the more sustainable one is the one with the smallest Ecological Footprint and the lowest input of Emergy. Further, for an option to be considered more sustainable, it must meet both criteria simultaneously. In mathematical form the criteria indicate that option one is more environmentally sustainable than option two when: $\mathrm{EF}_{1} \leq \mathrm{EF}_{2}$ and $\mathrm{Em}_{1} \leq \mathrm{Em}_{2}$.

\subsection{Emergy}

Emergy is generally meant to represent the sum total of the thermodynamic work done in producing a product or maintaining an operation using solar energy along with tidal and geothermal energy as energy sources. Note that solar energy input is by far the largest contributor to Emergy. For purposes of this work, Emergy is the sum of the total thermodynamic work done in producing a specific mass of cement. Emergy is expressed in solar energy Joules or seJ. The conversion factor between different kinds of energy in Joules or $\mathbf{J}$ and Emergy in se $\mathrm{J}$ is called a transformity. The application of Emergy theory also known as Energy Systems Theory is often known as Emergy accounting. In essence, Emergy accounting tries to transform all mass and energy flows into solar energy Joules.

Transformities are in general very specific to the material, e.g. the seJ of, for example, a kilogram of a particular type of coal. For practical use, it is easier to rely on unit Emergy 
1 values which can often be found in the literature (Rugani et al., 2011). These are 2 proportionality constants which convert a defined unit of a substance or a form of energy 3 produced at a specific location by a particular process into the equivalent seJ. For example, 4 the unit Emergy value of hard wood in Europe is approximately $1.16 \cdot 10^{14} \mathrm{seJ} / \mathrm{m}^{3}$ where the unit of wood is meters cube (Rugani et al., 2011). Unit Emergy values aggregate most of the contributions from the lifecycle of the product or process, and they differ in that respect from transformities which do not attempt to integrate the over life-cycle. For a product, for example cement, the Emergy is calculated from the expression,

$$
E m_{C P}=\sum_{m} E m_{m, C P}+\sum_{e} E m_{e, C P}
$$

where $\mathrm{Em}_{\mathrm{CP}}$ is the Emergy in seJ needed to produce cement " $\mathrm{C}$ " by process " $\mathrm{P}$," $\mathrm{Em}_{\mathrm{m}, \mathrm{CP}}$ is the Emergy of material input $m$ in seJ into process "P", Em $\mathrm{e}_{\mathrm{e}, \mathrm{CP}}$ is the Emergy of energy input "e" in seJ into process " $\mathrm{P}$ ", and the sum " $\mathrm{m}$ " is taken over all of the material inputs and the sum " $\mathrm{e}$ " is taken over all energy inputs into the process.

The Emergy of each material input is computed from,

$$
E m_{m, C P}=b_{m, S} \bullet K_{m, S}
$$

where $b_{m, S}$ is the unit Emergy in seJ of one kilogram of input "m" obtained or produced from source " $\mathrm{S}$ ", and $\mathrm{K}_{\mathrm{m}, \mathrm{S}}$ is the necessary number of kilograms of input " $\mathrm{m}$ ". Input " $\mathrm{m}$ " can be any material input needed, including manufactured products, e.g. chemicals, metals, waste, or agricultural products, e.g. wood, agricultural residue. However, care must be taken to match as closely as possible the actual process under study to the process used to derive the unit Emergy values. This includes matching as well as possible the geographical location, raw materials and their sources, technology used, etc.

When the input is a type of energy, the form of the expression is the same, but the interpretation of the terms is now different. For example,

$$
E m_{e, C P}=b_{e, S} \bullet K_{e, S}
$$

where $b_{e, S}$ is the unit Emergy in seJ of one kilowatt hour of energy of form "e" obtained or produced from source " $\mathrm{S}$ ", and $\mathrm{K}_{\mathrm{e}, \mathrm{S}}$ is the necessary number of kilowatt hours of energy " $\mathrm{e}$ ". The energy "e" can be any form of energy, e.g. electricity, heat, mechanical energy, generated by any process, e.g. solar electricity, thermo-electric generation, and waste heat. However, 
1 again, care must be taken to match as closely as possible the energy generation processes to geographical location, raw materials and their sources, technology used, etc.

\subsection{Ecological Footprint}

Ecological Footprint theory attempts to estimate the area needed to support a given human population or human activity such as a manufacturing process. This is the area needed to provide the required resources and dissipate the resulting waste. Ecological Footprint is measured in global hectares or gHa. For this purpose the required land area is divided into six kinds of land: arable land, forest land, pasture land, sea, energy land, and built land. The procedure to compute the Ecological Footprint is basically to estimate the amount of land area needed for each type of land and sum them up to obtain the Ecological Footprint. As Emergy accounting attempts to estimate the solar energy Joules corresponding to different products or to maintain processes, the Ecological Footprint tries to estimate the area in global hectares needed for producing different products or maintaining different processes.

As already mentioned, cement production is an energy intensive process, and the dominant component of the Ecological Footprint is due to the area needed to absorb the carbon dioxide emitted by the process. It is assumed that the carbon dioxide is absorbed by forest and the ocean. Hence, the Ecological Footprint $\mathrm{EF}_{\mathrm{C}}$ for cement production is calculated from:

$$
E F_{C}=\frac{P_{C} \bullet\left(1-S_{\text {Ocean }}\right)}{Y_{C}} \bullet E Q F
$$

where $\mathrm{P}_{\mathrm{C}}$ is the kilograms of carbon dioxide emitted by the cement production process, $\mathrm{S}_{\text {Ocean }}$ is the fraction of the carbon dioxide sequestered by the ocean, $Y_{c}$ is the average global yield of forest land sequestration in kilograms per hectare, and EQF is the equivalence factor. This factor has units of maximum productivity of forest land sequestration in kilograms divided by the average productivity of all land types in kilograms as well. It is used to convert hectares of forest land to global hectares (Ewing et al., 2010; Galli, 2015). Lastly, it is assumed that the ocean can sequester about $28 \%$ of the carbon dioxide so that $\mathrm{S}_{\text {Ocean }}=0.28$. Global yields $\mathrm{Y}_{\mathrm{c}}$ and equivalence factors can be obtained from the Global Footprint Network - GFN (GFN, 2008; GFN, 2015) or from the literature (Hopton and White, 2012).

\section{Mitigation scenarios}

Due to the energy intensity involved in cement manufacture, we focus on mitigation efforts that reduce $\mathrm{CO}_{2}$ emissions. However, for the reduction in $\mathrm{CO}_{2}$ emissions to represent an 
1 improvement towards sustainability, the aforementioned criteria of reducing the Ecological

2 Footprint and Emergy input must also be met. There are different effective mitigation measures to reduce $\mathrm{CO}_{2}$ emissions from cement manufacturing (Mikulčić et al., 2013b): (1) carbon capture and storage (CCS) technology; (2) reduction of clinker to cement ratio with the addition of different additives; (3) improving the energy efficiency of the kiln process; and (4) replacing fossil fuels with alternative fuels of predominately biomass origin. As most of the named measures are to a large extent affected by environmental policy and legal frameworks, the integration of these measures will only be possible under incentives and policies that foster the deployment of these measures in cement manufacturing. This applies in particular to carbon CCS technology due to its high cost.

The projected cement production of a particular cement plant is presented through four different scenarios. The first scenario, business-as-usual or BAU, can be considered as a reference scenario since the actual cement plant Emergy and Ecological Footprint are calculated. The other three are mitigation scenarios that integrate appropriate measures that will lower the fuel consumption and lessen $\mathrm{CO}_{2}$ emissions from cement production.

In these four scenarios an assumption was made that the same amount of cement is produced with the same hydraulic quality, meaning that the reduction of clinker to cement ratio with the addition of different additives is not considered as a mitigation measure in these scenarios. The improvement of the energy efficiency of the kiln process, and the replacement of fossil fuels with alternative fuels of predominately biomass origin are the two mitigation measures considered in the four scenarios. In this study, the $\mathrm{CO}_{2}$ emissions from the cement production have been calculated according to the IPCC methodology (IPCC, 2001).

\subsection{Business as usual scenario}

The BAU scenario is based on the exploitation of existing resources, needed for stable cement production. The studied cement plant uses a dry kiln with a four stage preheating tower. The specific thermal energy consumption of this cement plant is $3.67 \mathrm{GJ} / \mathrm{t}$ clinker. The BAU scenario does not include the implementation of any mitigation measure beyond those already in use. This scenario represents a reference level for the Emergy and Ecological Footprint analysis. This includes alternative fuels, such as discarded tyres, already used in the production process. The list of fuels can be found in Table 2 .

\subsection{Scenario 1 - Energy Efficient Kiln Process}

This first scenario assumes the inclusion of the most energy efficient kiln process in the cement manufacturing industry. Currently, the most energy efficient technology for cement 
1 production is a dry rotary kiln process with a multi-stage preheater and a cement calciner, which

2 has a specific energy consumption of 3 GJ per ton of clinker (Mikulčić et al. 2015). Here as in the BAU scenario, alternative fuels already used are included.

\subsection{Scenario 2 - Alternative Fuel}

In this second scenario, the assumption is made that the fraction of thermal energy produced by alternative fuels is $30 \%$. The value of $30 \%$ is chosen since no major capital investments are needed to substitute fossil fuels with alternative fuels up to this level. The alternative fuel considered in this scenario, in addition to those already used, is solid recovered fuel (SRF). SRF is defined as solid fuels prepared from non-hazardous waste materials intended for firing in industrial furnaces. The assumption is made that $60 \%$ of SRF is of biogenic origin, i.e. $\mathrm{CO}_{2}$ neutral (Mikulčić et al. 2014).

\subsection{Scenario 3 - Alternative Fuel and Efficient Kiln}

In this third scenario both the energy improvement of the kiln process and the use of increased share of SRF are considered. An assumption is made that the most energy efficient kiln process together with $30 \%$ of thermal energy fraction produced by SRF is used in the manufacturing process.

\section{Results and discussion}

In Table 2 the actual plant data and the corresponding calculated Emergy values for the BAU scenario are shown. The unit Emergy values listed in the table were taken from literature (Rugani et al. 2011). It can be observed that $60 \%$ of input Emergy ends up in the final product, i.e. cement. Furthermore, from the table, it can be seen that the biggest contributor $(\sim 44 \%)$ to the input Emergy of the overall cement manufacturing process comes from the high and low grade marl. This is due to their large input mass - several orders of magnitude higher than of other input materials - and relatively large unit emergy values. In Table 3 the Emergy values for three mitigation scenarios are shown. As already discussed, it can be observed that Emergy values do not differ much. This presents a challenge to sustainability improvements because marl, a calcium carbonate sedimentary rock which contains variable amounts of clays, is not easy to substitute in cement production. This brings up the possibly obvious but very important point that when attempting to improve the sustainability of the process by reducing the input of emergy, one has start with the numerically largest contribution, then the second largest, and so on down. This focuses 
1 attention on the inputs that really matter. For instance, taking the otherwise intuitive step of 2 reducing the input of coal and petrol coke is likely to lead only to a modest reduction in 3 Emergy input, because the total Emergy values of both are almost two orders of magnitude

In Table 4 the calculated masses of different fuels for all four scenarios are given. For the BAU scenario, the actual mass of the used fuels is given. For three other scenarios, masses of the fuels were calculated according to the previously specified assumptions. Again, Scenario 1 involves the use of the most efficient kiln process in the industry, Scenario 2 involves the production of $30 \%$ of the thermal energy from alternative fuels, and Scenario 3 uses an efficient kiln and alternative fuels both exactly as in Scenarios 1 and 2. As expected, the thermal energy needed is reduced only by the use of a more efficient kiln process. However, the consumption of coke and coal is significantly reduced by both the use of the more efficient kiln process and alternatives fuels, with the greatest reduction in Scenario 3 where both are combined. Compared to BAU, Scenario 3 reduces thermal energy needs by $-18 \%$, the thermal energy produced from coke by $-32 \%$, and the thermal energy produced from coal by $32 \%$ as well. This is significant, because under the assumption that alternative fuels are carbon neutral, this represents very roughly a $1 / 3$ reduction in carbon dioxide emissions. Alternative fuels are often, in any case, low value materials with low economic value and not too many other uses. Hence, their use in this application is probably environmentally and economically advantageous (Benhelal et al., 2013; Andrić et al., 2014).

In Table 5 the $\mathrm{CO}_{2}$ emissions and the Ecological Footprint for all four scenarios are shown. As can be seen the Ecological Footprint, as opposed to the Emergy, is a better indicator of the influence that different cement manufacturing processes have on the environment. This probably indicates the fact that for cement production the ecological footprint is dominated by the land area required to sequester carbon dioxide emissions. Further, as already discussed, cement production is an energy intensive process that is heavily dependent on fossil fuels. Hence, a reduction in fossil fuel use is most likely to be seen first in the ecological footprint rather than the emergy. The reduction in the ecological footprint 
1 compared to the BAU Scenario is as follows: Scenario 1 with the more efficient kiln 2 approximately $-8 \%$, Scenario 2 with the use of alternative fuels approximately $-4 \%$, and 3 Scenario 3 using both the more efficient kiln and alternative fuels approximately $-10 \%$. As expected, the lowest Ecological Footprint, and thus the lowest environmental impact corresponds to Scenario 3. Note, however, that the reductions are not quite additive, i.e. a more efficient kiln plus alternative fuels does not give about a $12 \%$ reduction in the ecological footprint. The complete explanation can be complex, but basically the more efficient kiln reduces the need for energy so there is opportunity to reduce the foot print with an alternative fuel.

\section{Conclusion}

In this study a combined Emergy and Ecological Footprint analysis along with an effort to reduce $\mathrm{CO}_{2}$ emissions was investigated. The combination of these two environmental indicators is used, in order to explore improving of the sustainability of cement manufacturing processes. Reduction of $\mathrm{CO}_{2}$ emissions was considered due to concerns over the exacerbation of climate change. To assess which manufacturing process is more sustainable at the lowest level of $\mathrm{CO}_{2}$ emissions, the environmental impact of four different cement manufacturing scenarios was considered: business as usual BAU, Scenario 1 - energy efficient kiln process, Scenario $2-30 \%$ of thermal energy produced by alternative fuel, and Scenario 3 - energy efficient kiln process together with $30 \%$ of thermal energy produced by alternative fuel. Actual cement plant data were used to correctly study the environmental impact of these four processes. The input of Emergy did not vary significantly among the four scenarios, but it certainly did not increase. Hence, the criterion that Emergy input should not increase for sustainability was met. The Ecological Footprint did decrease from the BAU scenarios by $8 \%$ for Scenario 1, $4 \%$ for Scenario 2, and $10 \%$ for Scenario 3. The emissions of $\mathrm{CO}_{2}$ correspondingly decreased by $8 \%, 4 \%$, and $10 \%$ respectively. Note that due to the dominance of $\mathrm{CO}_{2}$ emissions in the Ecological Footprint calculation, reductions in the Ecological Footprint mirror decreases in $\mathrm{CO}_{2}$ emissions, but this should by no means be taken as anything other than incidental event and certainly not a general rule. Finally, it can be argued that all three alternative scenarios are more sustainable than the BAU case. However,

31 it seems clear that Scenario 3, the combination of a more energy efficient kiln process together with the increased use of solid recovered fuel, is more sustainable, decreasing most significantly the impact that cement production has on the environment. 
Another important point when assessing sustainability and changes in the sustainability of manufacturing processes is the need to use multiple and reasonably independent metrics rather than combining everything into a single quantity. There are two reasons for this: (1) different metrics have different sensitivity to specific changes on the process, and (2) not all changes map with equal fidelity into different metrics. In our case for cement manufacturing, the ecological footprint directly translates the changes in the manufacturing process into a land area, and the signal from this metric is clear. On the other hand, emergy is dominated by the emergy in the marl which came from the sun long ago. Hence we see little change with our modifications of the manufacturing process. This does not mean that emergy is unimportant, rather it means that it is insensitive to these specific set of changes. It also illustrates the principle that less sustainability with respect to any single metric usually implies that the process is less sustainable with respect to the other metrics, even though for some metrics the signal may not observable because it does not rise above the uncertainty.

Lastly, the sustainability improvements that were explored in the present work are based on accessible modifications to an existing cement plant. As mentioned, much more could be achieved with the consideration of novel or revolutionary technologies, albeit at substantially higher capital investment. It is important, however, that the methodology being present here for the quantitative assessment of sustainability improvements is applicable regardless of the technology being used. It is, therefore, a generic and scientifically based assessment method useful beyond the current specific case.

\section{Acknowledgements}

The authors wish to thank Drs. Wesley Ingwersen, Xin "Cissy" Ma, Matthew Hopton, and Leisha Vance of the U.S. Environmental Protection Agency, Office of Research and Development for useful discussions and assistance with the Emergy and Ecological Footprint calculations. Heriberto Cabezas is grateful for the Embassy Science Fellowship with the U.S. Embassy in Zagreb, Croatia under which the present work was conducted.

\section{References}

Andrić, I., Jamali-Zghal, N., Santarelli, M., Lacarrière, B., Le Corre, O., 2014. Environmental performance assessment of retrofitting existing coal fired power plants to co-firing with biomass: carbon footprint and emergy approach. J. Clean. Prod. doi: 10.1016/j.jclepro.2014.08.019 
Benhelal, E., Zahedi, G., Shamsaei, E., Bahadori, A., 2013. Global strategies and potentials to curb $\mathrm{CO}_{2}$ emissions in cement industry. J. Clean. Prod. 51, 142-161.

Brunke, J.-C., Blesl, M., 2014. Energy conservation measures for the German cement industry and their ability to compensate for rising energy-related production costs. J. Clean. Prod. 82, 94-111.

Cagiao, J., Gómez, B., Doménech, J.L., Mainar, S.G., Lanza, H.G., 2011. Calculation of the corporate carbon footprint of the cement industry by the application of MC3 methodology. Ecol. Indic. 11, 1526-1540.

Chen, W., Hong, J., Xu, C., 2014. Pollutants generated by cement production in China, their impacts, and the potential for environmental improvement. J. Clean. Prod. doi: 10.1016/j.jclepro.2014.04.048

Čuček, L., Klemeš, J.J., Varbanov, P.S., Kravanja, Z., 2012a. Total footprints-based multicriteria optimisation of regional biomass energy supply chains. Energy 44, 135-145.

Čuček, L., Klemeš, J.J., Kravanja, Z., 2012b. A review of footprint analysis tools for monitoring impacts on sustainability. J. Clean. Prod. 34, 9-20.

Ekincioglu, O., Gurgun, A.P., Engin, Y., Tarhan, M., Kumbaracibasi, S., 2013. Approaches for sustainable cement production - A case study from Turkey. Energy Build. 66, 136-142.

Ewing, B., Reed, A., Galli, A., Kitzes, J., Wackernagel, M., 2010. Calculation Methodology for the National Footprint Accounts. 2010 Edition. Global Footprint Network, Oakland, CA.

Galli, A., 2015. On the rationale and policy usefulness of ecological footprint accounting: the case of Morocco. Environ. Sci. Policy 48, 210-224.

Global Footprint Network - GFN. National Footprint Accounts 2008 Partner Edition with 2005 data. Global Footprint Network: Oakland, CA, 2008.

Global Footprint Network - GFN, www.footprintnetwork.org/en/index.php/GFN/, accessed February 24, 2015.

Hasanbeigi, A., Menke, C., Price, L., 2010. The $\mathrm{CO}_{2}$ abatement cost curve for the Thailand cement industry. J. Clean. Prod. 18, 1509-1518.

Hopton, M.E., White, D., 2012. A simplified ecological footprint at a regional scale. J. Environ. Manag. 111, 279-286.

Huijbregts, M.A.J., Hellweg, S., Frischknecht, R., Hungerbühler, K., Hendriks, A.J., 2008. Ecological footprint accounting in the life cycle assessment of products. Ecol. Econ. 64, 798-807. 
1 IEA (International Energy Agency) Cement Technology Roadmap 2009: Carbon emissions reductions up to 2050. http://www.iea.org/publications/freepublications/publication/ Cement_Roadmap.pdf, accessed February 24, 2015.

IPCC, 2001. Good Practice Guidance and Uncertainty Management in National Greenhouse Gas Inventories. www.ipcc-nggip.iges.or.jp/public/gp/english/, accessed February 24, 2015.

IPCC, 2013: Climate Change 2013: The Physical Science Basis. Contribution of Working Group I to the Fifth Assessment Report of the Intergovernmental Panel on Climate Change [Stocker, T.F., D. Qin, G.-K. Plattner, M. Tignor, S.K. Allen, J. Boschung, A. Nauels, Y. Xia, V. Bex and P.M. Midgley (eds.)]. Cambridge University Press, Cambridge, United Kingdom and New York, NY, USA, 1535 pp.

IPCC Press Release, 2014/19/PR, 2014. http://www.ipcc.ch/pdf/ar5/pr_wg3/20140413 _pr_pc_wg3_en.pdf, accessed February 24, 2015.

Jamali-Zghal, N., Amponsah, N.Y., Lacarriere, B., Le Corre, O., Feidt, M., 2013. Carbon footprint and emergy combination for eco-environmental assessment of cleaner heat production. J. Clean. Prod. 47, 446-456.

Klemeš, J.J., Varbanov, P.S., Huisingh, D., 2012. Recent cleaner production advances in process monitoring and optimization. J. Clean. Prod. 34, 1-8.

Li, C., Nie, Z., Cui, S., Gong, X., Wang, Z., Meng, X., 2014. The life cycle inventory study of cement manufacture in China. J. Clean. Prod. 72, 204-211.

Liu, G., Yang, Z., Chen, B., Zhang, J., Liu, X., Zhang, Y., Su M., Ulgiati S., 2014. Scenarios for sewage sludge reduction and reuse in clinker production towards regional ecoindustrial development: a comparative emergy-based assessment. J. Clean. Prod. doi: 10.1016/j.jclepro.2014.09.003

Marques, M., Neves-Silva, R., 2015. Decision support for energy savings and emissions trading in industry. J. Clean. Prod. 88, 105-115.

Mikulčić, H., von Berg, E., Vujanović, M., Priesching, P., Tatschl, R., Duić, N., 2013a. Numerical analysis of cement calciner fuel efficiency and pollutant emissions. Clean. Techn. Environ. Policy 15, 489-499.

Mikulčić, H., Vujanović, M., Duić, N., 2013b. Reducing the $\mathrm{CO}_{2}$ emissions in Croatian cement industry. Appl. Energy 101, 41-48.

Mikulčić, H., Vujanović, M., Duić, N., 2015. Improving the Sustainability of Cement Production by Using Numerical Simulation of Limestone Thermal Degradation and Pulverized Coal Combustion in a Cement Calciner. J. Clean. Prod. 88, 262-271. 
1 Mikulčić, H., von Berg, E., Vujanović, M., Duić, N., 2014. Numerical study of co-firing pulverized coal and biomass inside a cement calciner. Waste Manag. Res. 32, 661-69.

Morrow, W.R, Hasanbeigi, A., Sathaye, J., Xu, T., 2014. Assessment of energy efficiency improvement and $\mathrm{CO}_{2}$ emission reduction potentials in India's cement and iron \& steel industries. J. Clean. Prod. 65, 131-141.

Moya, J.A., Pardo, N., Mercier, A., 2011. The potential for improvements in energy efficiency and $\mathrm{CO}_{2}$ emissions in the EU27 cement industry and the relationship with the capital budgeting decision criteria. J. Clean. Prod. 19, 1207-1215.

Nguyen, Q.A., Hens, L., 2013. Environmental performance of the cement industry in Vietnam: the influence of ISO 14001 certification. J. Clean. Prod. doi: 10.1016/j.jclepro.2013.09.032

Odum, H.T., Nilsson, P.O., 1996. Environmental accounting: emergy and environmental decision making. Wiley, New York.

Oh, D.-Y., Noguchi, T., Kitagaki, R., Park, W.-J., 2014. $\mathrm{CO}_{2}$ emission reduction by reuse of building material waste in the Japanese cement industry. Renew. Sustain. Energy Rev. 38, 796-810.

Ostad-Ahmad-Ghorabi, M.J., Attari, M., 2013. Advancing environmental evaluation in cement industry in Iran. J. Clean. Prod. 41, 23-30.

Pardo, N., Moya, J.A., Mercier, A., 2011. Prospective on the energy efficiency and $\mathrm{CO}_{2}$ emissions in the EU cement industry. Energy 36, 3244-3254.

Pulselli, R.M., Simoncini, E., Ridolfi, R., Bastianoni, S., 2008. Specific emergy of cement and concrete: An energy-based appraisal of building materials and their transport. Ecol. Indic. $8,647-56$.

Rugani, B., Huijbregts, M.A., Mutel, C., Bastianoni, S., Hellweg, S., 2011. Solar energy demand (SED) of commodity life cycles. Environ. Sci. Techn. 45, 5426-5433.

Rugani, B., Vázquez-Rowe, I., Benedetto, G., Benetto, E., 2013. A comprehensive review of carbon footprint analysis as an extended environmental indicator in the wine sector. $\mathrm{J}$. Clean. Prod. 54, 61-77.

Swanepoel, J.A., Mathews, E.H., Vosloo. J., Liebenberg, L., 2014. Integrated energy optimisation for the cement industry: A case study perspective. Energy Convers. Manag. $78,765-775$.

Usón, A.A., López-Sabirón, A.M., Ferreira, G., Sastresa, E.L., 2013. Uses of alternative fuels and raw materials in the cement industry as sustainable waste management options. Renew. Sustain. Energy Rev. 23, 242-260. 
Vance, L., Cabezas, H., Heckl, I., Bertok, B., Friedler, F., 2013. Synthesis of sustainable supply chain by the p-graph framework. Ind. Eng. Chem. Res. 52, 266-274.

Vance, L., Heckl, I., Bertok, B., Cabezas, H., Friedler, F., 2015. Designing sustainable energy supply chains by the p-graph method for minimal cost, environmental burden, energy resources input. J. Clean. Prod. doi: 10.1016/j.jclepro.2015.02.011

Wackernagel, M., Rees, W., 1996. Our Ecological Footprint. New Society Publishers, Gabriola Island, BC and Stony Creek, CT.

Wang, Y., Höller, S., Viebahn, P., Hao, Z., 2014. Integrated assessment of $\mathrm{CO}_{2}$ reduction technologies in China's cement industry. Int. J. Greenh. Gas Control 20, 27-36.

Wang, Y., Zhu, Q., Geng, Y., 2013. Trajectory and driving factors for GHG emissions in the Chinese cement industry. J. Clean. Prod. 53, 252-260.

World Commission on Environment and Development (WCED). Our Common Future. Oxford University Press, Oxford. 1987.

Worrell, E., Galitsky, C., 2008. Energy Efficiency Improvement and Cost Saving Opportunities for Cement Making, An ENERGY STAR ${ }^{\circledR}$ Guide for Energy and Plant Managers. Lawrence Berkeley National Laboratory: Berkeley, CA (LBNL-54036Revision).

Xu, J.-H., Fleiter, T., Fan, Y., Eichhammer, W., 2014. $\mathrm{CO}_{2}$ emissions reduction potential in China's cement industry compared to IEA's Cement Technology Roadmap up to 2050. Appl. Energy 130, 592-602.

Xu, T., Galama, T., Sathaye, J., 2013. Reducing carbon footprint in cement material making: Characterizing costs of conserved energy and reduced carbon emissions. Sustain. Cities Soc. 9, 54-61.

Zhang, B., Chen, G.Q., Yang, Q., Chen, Z.M., Chen, B., Li, Z., 2011. How to guide a sustainable industrial economy: Emergy account for resources input of Chinese industry. Procedia Environ. Sci. 5, 51-59.

\section{Table captions}

Table 1 Global cement production in 2012 (Oh et al., 2014).

Table 2 Emergy calculation for the BAU scenario.

Table 3 Emergy calculation for the three mitigation scenarios.

Table 4 Calculation of the fuel masses according to the thermal energy need for three mitigation scenario.

Table $5 \mathrm{CO}_{2}$ emissions and Ecological Footprint calculation. 
Table 1

Global cement production in 2012 (Oh et al., 2014).

\begin{tabular}{lrr}
\hline Country & $\begin{array}{r}\text { Production } \\
\text { (million metric } \\
\text { tonnes) }\end{array}$ & $\begin{array}{r}\text { Share in the } \\
\text { world production }\end{array}$ \\
\hline China & 2150 & $58.1 \%$ \\
India & 250 & $6.7 \%$ \\
United States & 74 & $2.0 \%$ \\
Brazil & 70 & $1.9 \%$ \\
Iran & 65 & $1.8 \%$ \\
Vietnam & 65 & $1.8 \%$ \\
Turkey & 60 & $1.6 \%$ \\
Russian Federation & 60 & $1.6 \%$ \\
Japan & 52 & $1.4 \%$ \\
South Korea & 49 & $1.3 \%$ \\
Egypt & 44 & $1.2 \%$ \\
Saudi Arabia & 43 & $1.2 \%$ \\
Mexico & 36 & $1.0 \%$ \\
Germany & 34 & $0.9 \%$ \\
Thailand & 33 & $0.9 \%$ \\
Pakistan & 32 & $0.9 \%$ \\
Italy & 32 & $0.9 \%$ \\
Indonesia & 31 & $0.8 \%$ \\
Spain & 20 & $0.5 \%$ \\
Other (rounded) & 500 & $13.5 \%$ \\
World total (rounded) & 3700 & - \\
\hline
\end{tabular}


Table 2

Emergy calculation for the BAU scenario.*

\begin{tabular}{|c|c|c|c|c|c|c|}
\hline \multicolumn{7}{|c|}{ Cement plant technical data for BAU scenario } \\
\hline & Quantity & Unit & $\begin{array}{l}\text { Unit Emergy } \\
\text { Values }\end{array}$ & Units \& Details & Emergy Calculation & Units \& Details \\
\hline \multicolumn{7}{|l|}{ MAIN DATA } \\
\hline Clinker Production & $3.15 \mathrm{E}+05$ & $\mathrm{t}$ & $1.28 \mathrm{E}+13$ & seJ/kg (Switzerland) & $4.02 E+21$ & seJ \\
\hline $\begin{array}{l}\text { Specific Thermal Energy } \\
\text { Consumption }\end{array}$ & $3.67 \mathrm{E}+03$ & $\mathrm{MJ} / \mathrm{t}$ clinker & & & & \\
\hline Cement Production & $3.91 \mathrm{E}+05$ & $\mathrm{t}$ & $1.07 \mathrm{E}+13$ & seJ/kg (Switzerland) & 4.17E+21 & seJ (Cement produced) \\
\hline $\begin{array}{l}\text { Specific Electrical Energy } \\
\text { Consumption }\end{array}$ & $9.03 E+01$ & $\begin{array}{l}\mathrm{kWh} / \mathrm{t} \\
\text { cement }\end{array}$ & & & & \\
\hline $\begin{array}{l}\text { Total Electrical Energy } \\
\text { Consumption }\end{array}$ & $3.82 \mathrm{E}+07$ & kWh & $8.43 E+11$ & seJ/kWh (Austria mix) & $3.22 \mathrm{E}+19$ & seJ \\
\hline Electrical Energy per Ton of Clinker & 121 & $\mathrm{kWh} / \mathrm{t}$ clinker & & & & \\
\hline \multicolumn{7}{|l|}{ INPUT } \\
\hline \multicolumn{7}{|l|}{ Raw Materials for clinker production } \\
\hline High grade marl & $1.90 \mathrm{E}+05$ & $\mathrm{t}$ & $7.61 \mathrm{E}+12$ & seJ/kg (Switzerland) & $1.45 \mathrm{E}+21$ & seJ \\
\hline Low grade marl & $3.18 \mathrm{E}+05$ & $\mathrm{t}$ & $7.61 \mathrm{E}+12$ & seJ/kg (Switzerland) & $2.42 E+21$ & seJ \\
\hline Quartz sand & $1.89 \mathrm{E}+03$ & $\mathrm{t}$ & $1.13 \mathrm{E}+14$ & seJ/kg (subsoil) & $2.14 \mathrm{E}+20$ & seJ \\
\hline Iron oxide & $1.78 \mathrm{E}+03$ & $\mathrm{t}$ & $1.06 \mathrm{E}+13$ & $\begin{array}{l}\mathrm{seJ} / \mathrm{kg} \text { (Iron, element mass ratio in Taconite minerals; } \\
\{\mathrm{Fe} 2 \mathrm{O} 3, \mathrm{Fe} 3+2 \mathrm{Fe} 2+\mathrm{O} 4 \text {, and } \mathrm{Fe} 2+\mathrm{CO} 3\} ; 0.1 \mathrm{~g} / \mathrm{g} \text { in ground) }\end{array}$ & $1.88 \mathrm{E}+19$ & seJ \\
\hline \multicolumn{7}{|l|}{ Fuels for clinker production } \\
\hline Coal & $2.16 \mathrm{E}+04$ & $\mathrm{t}$ & $3.74 \mathrm{E}+12$ & seJ/kg (Austria Hard Supply Mix) & $8.06 \mathrm{E}+19$ & seJ \\
\hline Petrol Coke & $1.36 \mathrm{E}+04$ & $\mathrm{t}$ & $6.57 \mathrm{E}+12$ & seJ/kg (Europe petroleum coke at refinery) & $8.92 \mathrm{E}+19$ & seJ \\
\hline Heavy fuel oil & 369 & $\mathrm{t}$ & $5.76 \mathrm{E}+12$ & $\mathrm{seJ} / \mathrm{kg}$ (Europe regional storage) & $2.13 \mathrm{E}+18$ & seJ \\
\hline Tyres & $2.59 \mathrm{E}+03$ & $\mathrm{t}$ & $3.39 \mathrm{E}+12$ & seJ/kg (Switzerland rubber municipal incineration) & $8.79 \mathrm{E}+18$ & seJ \\
\hline Waste Oil & $1.29 E+03$ & $\mathrm{t}$ & $9.07 \mathrm{E}+12$ & seJ/kg (Europe lubricating oil at plant) & $1.18 \mathrm{E}+19$ & seJ \\
\hline SRF & $4.18 \mathrm{E}+03$ & $\mathrm{t}$ & $9.45 \mathrm{E}+11$ & $\begin{array}{l}\mathrm{seJ} / \mathrm{kg} \text { (Europe 60\% paper @ 3.11E5 SEJ } / \mathrm{kg}+\text { Switzerland } \\
40 \% \text { mixed platics @ 1/2[2.46E5+1.69E6]) }\end{array}$ & $3.95 \mathrm{E}+18$ & seJ \\
\hline
\end{tabular}




\begin{tabular}{|c|c|c|c|c|c|c|}
\hline Chemical Gypsum & $1.33 \mathrm{E}+04$ & $\mathrm{t}$ & $1.65 \mathrm{E}+14$ & seJ/kg (Switzerland, mineral at mine) & $2.19 \mathrm{E}+21$ & seJ \\
\hline Blast Furnace Slag & $2.34 \mathrm{E}+04$ & $\mathrm{t}$ & $5.98 \mathrm{E}+12$ & $\mathrm{seJ} / \mathrm{kg}$ (Switzerland, blast funance cement plant) & $1.40 \mathrm{E}+20$ & seJ \\
\hline Limestone & $2.51 \mathrm{E}+04$ & $\mathrm{t}$ & $9.09 \mathrm{E}+12$ & $\mathrm{seJ} / \mathrm{kg}$ (Switzerland milled loose at plant) & $2.29 \mathrm{E}+20$ & seJ \\
\hline Fly ash & $4.87 \mathrm{E}+04$ & $\mathrm{t}$ & $4.66 \mathrm{E}+11$ & $\mathrm{seJ} / \mathrm{kg}$ (Austria disposal of hard coal ash to landfill) & $2.27 \mathrm{E}+19$ & seJ \\
\hline \multicolumn{7}{|c|}{ Fuel for drying in cement production } \\
\hline Light oil & 459 & $\mathrm{t}$ & $5.88 \mathrm{E}+12$ & seJ/kg (Europe light fuel oil at regional storage) & $2.70 \mathrm{E}+18$ & seJ \\
\hline \multicolumn{7}{|l|}{ Air mass } \\
\hline Air for burning & $5.27 \mathrm{E}+05$ & $\mathrm{t}$ & $2.58 \mathrm{E}+07$ & $\mathrm{seJ} / \mathrm{kg}$ & $1.36 \mathrm{E}+16$ & seJ \\
\hline Air excess at preheater outles & $6.41 \mathrm{E}+05$ & $\mathrm{t}$ & $2.58 \mathrm{E}+07$ & $\mathrm{seJ} / \mathrm{kg}$ & $1.65 \mathrm{E}+16$ & seJ \\
\hline \multicolumn{7}{|l|}{ Water mass } \\
\hline $\begin{array}{l}\text { Water for cooling of hot gases } \\
\text { before main filter }\end{array}$ & $4.42 \mathrm{E}+04$ & $\mathrm{t}$ & $1.22 \mathrm{E}+09$ & seJ/kg (Europe completely softened at plant) & $5.40 \mathrm{E}+16$ & seJ \\
\hline Water for equipment cooling & $2.50 \mathrm{E}+03$ & $\mathrm{t}$ & $1.22 \mathrm{E}+09$ & seJ/kg (Europe completely softened at plant) & $3.05 \mathrm{E}+15$ & seJ \\
\hline & & & & & $6.85 E+21$ & seJ (Sum of input) \\
\hline \multicolumn{7}{|l|}{ OUTPUT } \\
\hline \multicolumn{7}{|l|}{ Air mass } \\
\hline Air at chimney & $1.12 \mathrm{E}+06$ & $\mathrm{t}$ & $1.29 \mathrm{E}+09$ & $\mathrm{seJ} / \mathrm{kg}$ & $1.44 \mathrm{E}+18$ & seJ \\
\hline Absolute Gross $\mathrm{CO}_{2}$ Emissions & $2.78 \mathrm{E}+05$ & $\mathrm{t}$ & $6.26 \mathrm{E}+07$ & $\mathrm{seJ} / \mathrm{kg}$ & $1.74 \mathrm{E}+16$ & seJ \\
\hline \multicolumn{7}{|l|}{ Thermal loses } \\
\hline Radiation loses & 173 & MJ/t clinker & $9.90 \mathrm{E}+11$ & seJ/kg clinker & $3.12 \mathrm{E}+20$ & seJ \\
\hline & & & & & $3.14 \mathrm{E}+20$ & seJ (Sum of output) \\
\hline
\end{tabular}

* To simplify the formatting of tables, in Tables 2-5 the $\mathrm{E}$ is used as a replacement for 10 , meaning that if as an example a value of $2.58 \mathrm{E}+07$ is given in the table, the actual value is $2.58 \cdot 10^{7}$. 
Table 3

Emergy calculation for the three mitigation scenarios.

\begin{tabular}{|c|c|c|c|c|c|c|c|}
\hline & Scenario 1 & Scenario 2 & Scenario 3 & & Scenario 1 & Scenario 2 & Scenario 3 \\
\hline & \multicolumn{3}{|c|}{ Quantity } & Unit & \multicolumn{3}{|c|}{ Emergy Calculation (seJ) } \\
\hline \multicolumn{8}{|l|}{ MAIN DATA } \\
\hline Clinker Production & \multicolumn{3}{|c|}{$3.15 E+05$} & $\mathrm{t}$ & \multicolumn{3}{|c|}{$4.02 \mathrm{E}+21$} \\
\hline Specific Thermal Energy Consumption & $3.00 \mathrm{E}+03$ & $3.67 \mathrm{E}+03$ & $3.00 \mathrm{E}+03$ & MJ/t clinker & & & \\
\hline Cement Production & \multicolumn{3}{|c|}{$3.91 \mathrm{E}+05$} & $\mathrm{t}$ & \multicolumn{3}{|c|}{ 4.18E+21 (Cement produced) } \\
\hline Specific Electrical Energy Consumption & \multicolumn{3}{|c|}{90.3} & $\mathrm{kWh} / \mathrm{t}$ cement & & & \\
\hline Total Electrical Energy Consumption & \multicolumn{3}{|c|}{$3.82 \mathrm{E}+07$} & kWh & \multicolumn{3}{|c|}{$3.22 \mathrm{E}+19$} \\
\hline Electrical Energy per Ton of Clinker & \multicolumn{3}{|c|}{121} & kWh/t clinker & & & \\
\hline \multicolumn{8}{|l|}{ INPUT } \\
\hline \multicolumn{8}{|l|}{ Raw Materials for clinker production } \\
\hline High grade marl & \multicolumn{3}{|c|}{$1.90 \mathrm{E}+05$} & $\mathrm{t}$ & \multicolumn{3}{|c|}{$1.45 E+21$} \\
\hline Low grade marl & \multicolumn{3}{|c|}{$3.18 \mathrm{E}+05$} & $\mathrm{t}$ & \multicolumn{3}{|c|}{$2.42 E+21$} \\
\hline Quartz sand & \multicolumn{3}{|c|}{$1.89 \mathrm{E}+03$} & $\mathrm{t}$ & \multicolumn{3}{|c|}{$2.14 \mathrm{E}+20$} \\
\hline Iron oxide & \multicolumn{3}{|c|}{$1.78 \mathrm{E}+03$} & $\mathrm{t}$ & \multicolumn{3}{|c|}{$1.88 \mathrm{E}+19$} \\
\hline \multicolumn{8}{|l|}{ Fuels for clinker production } \\
\hline Coal & $1.68 \mathrm{E}+04$ & $1.79 \mathrm{E}+04$ & $1.46 \mathrm{E}+04$ & $\mathrm{t}$ & $6.27 \mathrm{E}+19$ & $6.69 \mathrm{E}+19$ & $5.45 \mathrm{E}+19$ \\
\hline Petrol Coke & $1.06 \mathrm{E}+04$ & $1.13 \mathrm{E}+04$ & $9.19 E+03$ & $\mathrm{t}$ & $6.94 \mathrm{E}+19$ & $7.41 \mathrm{E}+19$ & $6.04 \mathrm{E}+19$ \\
\hline Heavy fuel oil & \multicolumn{3}{|c|}{369} & $\mathrm{t}$ & \multicolumn{3}{|c|}{$2.13 \mathrm{E}+18$} \\
\hline Tyres & \multicolumn{3}{|c|}{$2.59 E+03$} & $\mathrm{t}$ & \multicolumn{3}{|c|}{$8.79 \mathrm{E}+18$} \\
\hline Waste Oil & \multicolumn{3}{|c|}{$1.29 \mathrm{E}+03$} & $\mathrm{t}$ & \multicolumn{3}{|c|}{$1.18 \mathrm{E}+19$} \\
\hline SRF & $4.18 \mathrm{E}+03$ & $1.37 \mathrm{E}+04$ & $9.90 \mathrm{E}+03$ & $\mathrm{t}$ & $3.95 \mathrm{E}+18$ & $1.30 \mathrm{E}+19$ & $9.36 \mathrm{E}+18$ \\
\hline \multicolumn{8}{|l|}{ Mineral components for cement production } \\
\hline Chemical Gypsum & \multicolumn{3}{|c|}{$1.33 \mathrm{E}+04$} & $\mathrm{t}$ & \multicolumn{3}{|c|}{$2.19 \mathrm{E}+21$} \\
\hline Blast Furnace Slag & \multicolumn{3}{|c|}{$2.34 \mathrm{E}+04$} & $\mathrm{t}$ & \multicolumn{3}{|c|}{$1.40 \mathrm{E}+20$} \\
\hline
\end{tabular}




\begin{tabular}{|c|c|c|c|c|c|c|c|}
\hline Limestone & \multicolumn{3}{|c|}{$2.51 \mathrm{E}+04$} & $\mathrm{t}$ & \multicolumn{3}{|c|}{$2.29 \mathrm{E}+20$} \\
\hline Fly ash & \multicolumn{3}{|c|}{$4.87 \mathrm{E}+04$} & $\mathrm{t}$ & \multicolumn{3}{|c|}{$2.27 \mathrm{E}+19$} \\
\hline \multicolumn{8}{|l|}{ Fuel for drying in cement production } \\
\hline Light oil & \multicolumn{3}{|c|}{459} & $\mathrm{t}$ & \multicolumn{3}{|c|}{$2.70 \mathrm{E}+18$} \\
\hline \multicolumn{8}{|l|}{ Air mass } \\
\hline Air for burning & \multicolumn{3}{|c|}{$5.27 \mathrm{E}+05$} & $\mathrm{t}$ & \multicolumn{3}{|c|}{$1.36 \mathrm{E}+16$} \\
\hline Air excess at preheater outles & \multicolumn{3}{|c|}{$6.41 \mathrm{E}+05$} & $\mathrm{t}$ & \multicolumn{3}{|c|}{$1.65 \mathrm{E}+16$} \\
\hline \multicolumn{8}{|l|}{ Water mass } \\
\hline $\begin{array}{l}\text { Water for cooling of hot gases before } \\
\text { main filter }\end{array}$ & \multicolumn{3}{|c|}{$4.42 \mathrm{E}+04$} & $\mathrm{t}$ & \multicolumn{3}{|c|}{$5.40 \mathrm{E}+16$} \\
\hline Water for equipment cooling & \multicolumn{3}{|c|}{$2.50 \mathrm{E}+03$} & $\mathrm{t}$ & \multicolumn{3}{|c|}{$3.05 E+15$} \\
\hline & & & & & $6.82 E+21$ (Sum of input) & $6.82 E+21$ (Sum of input) & $6.80 E+21$ (Sum of input) \\
\hline \multicolumn{8}{|l|}{ OUTPUT } \\
\hline \multicolumn{8}{|l|}{ Air mass } \\
\hline Air at chimney & \multicolumn{3}{|c|}{$1.12 \mathrm{E}+06$} & $\mathrm{t}$ & \multicolumn{3}{|c|}{$1.44 \mathrm{E}+18$} \\
\hline Absolute Gross $\mathrm{CO}_{2}$ Emissions & $2.56 \mathrm{E}+05$ & $2.67 \mathrm{E}+05$ & $2.42 \mathrm{E}+05$ & $\mathrm{t}$ & $1.60 \mathrm{E}+16$ & $1.67 \mathrm{E}+16$ & $1.52 \mathrm{E}+16$ \\
\hline \multicolumn{8}{|l|}{ Thermal loses } \\
\hline Radiation loses & \multicolumn{3}{|c|}{173} & MJ/t clinker & \multicolumn{3}{|c|}{$3.12 \mathrm{E}+20$} \\
\hline & & & & & \multicolumn{3}{|c|}{$3.14 E+20$ (Sum of output) } \\
\hline
\end{tabular}




\section{Table 4}

Calculation of the fuel masses according to the thermal energy need for three mitigation scenario.

\begin{tabular}{|c|c|c|c|c|}
\hline & BAU Scenario & Scenario 1 & Scenario 2 & Scenario 3 \\
\hline Clinker production (t/y) & \multicolumn{4}{|c|}{$3.15 E+05$} \\
\hline Specific Thermal Energy Consumption (GJ/t) & 3.67 & 3.00 & 3.67 & 3.00 \\
\hline Thermal energy needed (GJ/y) & $1.16 \mathrm{E}+06$ & $9.46 \mathrm{E}+05$ & $1.16 \mathrm{E}+06$ & $9.46 \mathrm{E}+05$ \\
\hline Petrol coke - NCV (GJ/t) & \multicolumn{4}{|c|}{31.8} \\
\hline Petrol coke - used (t/y) & $1.36 \mathrm{E}+04$ & $1.056 \mathrm{E}+04$ & $1.13 \mathrm{E}+04$ & $9.18 \mathrm{E}+03$ \\
\hline $\begin{array}{l}\text { Thermal energy produced from Petrol coke } \\
(\mathrm{GJ} / \mathrm{y})\end{array}$ & $4.32 \mathrm{E}+05$ & $3.36 \mathrm{E}+05$ & $3.58 \mathrm{E}+05$ & $2.92 \mathrm{E}+05$ \\
\hline Coal - NCV (GJ/t) & \multicolumn{4}{|c|}{24.3} \\
\hline Coal - used (t/y) & $2.16 \mathrm{E}+04$ & $1.68 \mathrm{E}+04$ & $1.79 \mathrm{E}+04$ & $1.46 \mathrm{E}+04$ \\
\hline Thermal energy produced from Coal (GJ/y) & $5.25 \mathrm{E}+05$ & $4.08 \mathrm{E}+05$ & $4.36 \mathrm{E}+05$ & $3.55 \mathrm{E}+05$ \\
\hline Heavy fuel oil - NCV (GJ/t) & \multicolumn{4}{|c|}{40.8} \\
\hline Heavy fuel oil - used (t/y) & \multicolumn{4}{|c|}{369} \\
\hline $\begin{array}{l}\text { Thermal energy produced from Heavy fuel oil } \\
(\mathrm{GJ} / \mathrm{y})\end{array}$ & \multicolumn{4}{|c|}{$1.51 \mathrm{E}+04$} \\
\hline Tyres - NCV (GJ/t) & \multicolumn{4}{|c|}{26.4} \\
\hline Tyres - used (t/y) & \multicolumn{4}{|c|}{$2.59 \mathrm{E}+03$} \\
\hline Thermal energy produced from Tyres (GJ/y) & \multicolumn{4}{|c|}{$6.84 \mathrm{E}+04$} \\
\hline Waste Oil - NCV (GJ/t) & \multicolumn{4}{|c|}{35.9} \\
\hline Waste Oil - used (t/y) & \multicolumn{4}{|c|}{$1.29 \mathrm{E}+03$} \\
\hline Thermal energy produced from Waste oil (GJ/y) & \multicolumn{4}{|c|}{$4.66 \mathrm{E}+04$} \\
\hline SRF - NCV (GJ/t) & \multicolumn{4}{|c|}{16.9} \\
\hline SRF - used (t/y) & \multicolumn{2}{|c|}{$4.18 \mathrm{E}+03$} & 1.37E+04 & $9.90 \mathrm{E}+03$ \\
\hline Thermal energy produced from SRF (GJ/y) & \multicolumn{2}{|c|}{$7.11 \mathrm{E}+04$} & $2.33 \mathrm{E}+05$ & $1.68 \mathrm{E}+05$ \\
\hline
\end{tabular}


Table 5

$\mathrm{CO}_{2}$ emissions and Ecological Footprint calculation.

\begin{tabular}{|c|c|c|c|c|}
\hline & BAU Scenario & Scenario 1 & Scenario 2 & Scenario 3 \\
\hline Petrol coke - used (t/y) & $1.36 \mathrm{E}+04$ & $1.06 \mathrm{E}+04$ & $1.13 \mathrm{E}+04$ & $9.19 E+03$ \\
\hline Petrol coke - NCV (GJ/t) & \multicolumn{4}{|c|}{33.5} \\
\hline Emission factor $\left(\mathrm{kgCO}_{2} / \mathrm{GJ}\right)$ & \multicolumn{4}{|c|}{94.0} \\
\hline Oxidation factor & \multicolumn{4}{|c|}{1.00} \\
\hline $\mathrm{CO}_{2}$ Emissions Petrol coke - calculated $(\mathrm{kg} / \mathrm{y})$ & $4.27 \mathrm{E}+07$ & $3.33 \mathrm{E}+07$ & $3.55 \mathrm{E}+07$ & $2.89 \mathrm{E}+07$ \\
\hline Coal - used (t/y) & $2.15 \mathrm{E}+04$ & $1.68 \mathrm{E}+04$ & $1.79 \mathrm{E}+04$ & $1.46 \mathrm{E}+04$ \\
\hline Coal - NCV (GJ/t) & \multicolumn{4}{|c|}{24.3} \\
\hline Emission factor $\left(\mathrm{kgCO}_{2} / \mathrm{GJ}\right)$ & \multicolumn{4}{|c|}{$9 . .3$} \\
\hline Oxidation factor & \multicolumn{4}{|c|}{1.00} \\
\hline $\mathrm{CO}_{2}$ Emissions Coal - calculated $(\mathrm{kg} / \mathrm{y})$ & $5.16 \mathrm{E}+07$ & $4.01 E+07$ & $4.28 \mathrm{E}+07$ & $3.49 E+07$ \\
\hline Heavy fuel oil - used (t/y) & \multicolumn{4}{|c|}{369} \\
\hline Heavy fuel oil - NCV (GJ/t) & \multicolumn{4}{|c|}{40.8} \\
\hline Emission factor $\left(\mathrm{kgCO}_{2} / \mathrm{GJ}\right)$ & \multicolumn{4}{|c|}{77.4} \\
\hline Oxidation factor & \multicolumn{4}{|c|}{1.00} \\
\hline $\mathrm{CO}_{2}$ Emissions Heavy fuel oil - calculated $(\mathrm{kg} / \mathrm{y})$ & \multicolumn{4}{|c|}{$1.17 \mathrm{E}+06$} \\
\hline Tyres - used (t/y) & \multicolumn{4}{|c|}{$2.59 \mathrm{E}+03$} \\
\hline Tyres - NCV (GJ/t) & \multicolumn{4}{|c|}{35.9} \\
\hline Emission factor $\left(\mathrm{kgCO}_{2} / \mathrm{GJ}\right)$ & \multicolumn{4}{|c|}{85.0} \\
\hline Oxidation factor & \multicolumn{4}{|c|}{1.00} \\
\hline $\mathrm{CO}_{2}$ Emissions Tyres - calculated $(\mathrm{kg} / \mathrm{y})$ & \multicolumn{4}{|c|}{$7.92 \mathrm{E}+06$} \\
\hline Waste Oil - used (t/y) & \multicolumn{4}{|c|}{$1.29 \mathrm{E}+03$} \\
\hline Waste Oil - NCV (GJ/t) & \multicolumn{4}{|c|}{35.9} \\
\hline Emission factor $\left(\mathrm{kgCO}_{2} / \mathrm{GJ}\right)$ & \multicolumn{4}{|c|}{80.0} \\
\hline Oxidation factor & \multicolumn{4}{|c|}{1.00} \\
\hline $\mathrm{CO}_{2}$ Emissions Waste Oil - calculated (kg/y) & \multicolumn{4}{|c|}{$3.73 E+06$} \\
\hline
\end{tabular}




\begin{tabular}{|c|c|c|c|c|}
\hline SRF - used (t/y) & $4.18 \mathrm{E}+03$ & $4.18 \mathrm{E}+03$ & $1.37 \mathrm{E}+04$ & $9.90 \mathrm{E}+03$ \\
\hline SRF - NCV (GJ/t) & \multicolumn{4}{|c|}{16.9} \\
\hline Emission factor $\left(\mathrm{kgCO}_{2} / \mathrm{GJ}\right)$ & \multicolumn{4}{|c|}{95.7} \\
\hline Biogenic fraction $(\%)$ & \multicolumn{4}{|c|}{60.0} \\
\hline Oxidation factor & \multicolumn{4}{|c|}{1.00} \\
\hline Fossil Fraction Emission factor $\left(\mathrm{kgCO}_{2} / \mathrm{GJ}\right)$ & \multicolumn{4}{|c|}{37.4} \\
\hline $\mathrm{CO}_{2}$ Emissions SRF - calculated $(\mathrm{kg} / \mathrm{y})$ & $2.66 \mathrm{E}+06$ & $2.66 \mathrm{E}+06$ & $8.71 \mathrm{E}+06$ & $6.29 \mathrm{E}+06$ \\
\hline Total Fuel $\mathrm{CO}_{2}$ Emissions - calculated $(\mathrm{kg} / \mathrm{y})$ & $1.10 \mathrm{E}+08$ & $8.89 \mathrm{E}+07$ & $9.99 E+07$ & $8.29 E+07$ \\
\hline Process Plant $\mathrm{CO}_{2}$ Emissions - given from plant $(\mathrm{kg} / \mathrm{y})$ & \multicolumn{4}{|c|}{$1.67 \mathrm{E}+08$} \\
\hline Annual Plant $\mathrm{CO}_{2}$ Emissions $(\mathrm{kg})\left[\mathrm{P}_{\mathrm{C}}\right]$ & $2.78 \mathrm{E}+08$ & $2.56 \mathrm{E}+08$ & $2.67 \mathrm{E}+08$ & $2.50 \mathrm{E}+08$ \\
\hline Fraction of $\mathrm{CO}_{2}$ sequestered by the ocean $\left[\mathrm{S}_{\text {Ocean }}\right]$ & \multicolumn{4}{|c|}{0.28} \\
\hline Average global yield $(\mathrm{kg} / \mathrm{gHa})\left[\mathrm{Y}_{\mathrm{c}}\right]$ & \multicolumn{4}{|c|}{3.59} \\
\hline Equivalence factor [EQF] & \multicolumn{4}{|c|}{1.26} \\
\hline Ecological Footprint $(\mathrm{gHa})\left[\mathrm{EF}_{\mathrm{C}}\right]$ & $7.01 \mathrm{E}+04$ & $6.47 \mathrm{E}+04$ & $6.75 \mathrm{E}+04$ & $6.32 E+04$ \\
\hline
\end{tabular}

